Article

\title{
From Paris to the End of Oil
}

\author{
Dag Harald Claes * and Helge Hveem \\ Department of Political Science, University of Oslo, 0317 Oslo, Norway; E-Mails: d.h.claes@stv.uio.no (D.H.C.), \\ helge.hveem@stv.uio.no (H.H.) \\ * Corresponding author
}

Submitted: 20 April 2016 | Accepted: 6 July 2016 | Published: 8 September 2016

\begin{abstract}
This article discusses the possibilities and obstacles for a cost-effective implementation of policies that will lead to a significant reduction in global $\mathrm{CO} 2$ emissions from the use of oil. The structural conditions and economic consequences of changing national or regional energy systems vary dramatically. In addition, there are a large number of actors with strong interests along the energy value chain that may potentially halt, delay or alter the implementation of the Paris treaty. We analyze these issues by first locating oil in the overall energy system, then identifying possibilities and obstacles at various stages of the oil value chain, and finally by contextualizing global oil by discussing whether and how it may be affected by geopolitics and regional conflict. In brief, our argument is that developments in consumption volumes and patterns will be most important. Market forces are vital, but they are influenced by politics and public policy outcomes. Transportation is the most important sector for oil consumption, with changes in transport behavior, modes and technology being vital drivers. The behavior of investors will be a decisive factor in shaping the production side of the oil system. If investments go down as a response to lasting low oil prices and/or because investors decide to turn to green economy options, the supply of oil will logically shrink. On the other hand, the growth and development aspirations of a rapidly growing population in developing countries are likely to stimulate demand and thus increase exploration, production and subsequently the price. Finally, we emphasize the importance of (geo)politics influencing all aspects of the value chain of oil.
\end{abstract}

\section{Keywords}

climate change; energy system; oil market; Paris treaty

\section{Issue}

This article is part of the issue "Climate Governance and the Paris Agreement", edited by Jon Hovi and Tora Skodvin (University of Oslo, Norway).

(C) 2016 by the authors; licensee Cogitatio (Lisbon, Portugal). This article is licensed under a Creative Commons Attribution 4.0 International License (CC BY).

\section{Introduction}

The Paris treaty is an impressive achievement in international diplomacy. Before the conference, a deal along the lines of the outcome would have been regarded as impossible by most analysts. A total of 195 countries signed the Paris treaty, and most of them will ratify it. As other contributors to this volume demonstrate, the treaty is not just based on voluntarism. However, the willingness of signatories and their capacity to implement the treaty vary. Still, Paris will affect policymaking processes, both directly and indirectly: directly in terms of putting pressure on governments to honor promises of climate warming abatement action and indirectly in the sense that the general public will be more inclined to accept changes in energy usage.

At the same time, the structural conditions and economic consequences of changing national or regional energy systems vary dramatically. There are a large number of actors with strong interests and the capacity to exercise both economic and political power along the energy value chain. They may potentially halt, delay or alter the implementation of the Paris treaty. We analyze these issues by first locating oil in the overall energy sys- 
tem, then identifying the possibilities and obstacles at various stages of the oil value chain, and finally contextualizing global oil by discussing whether and how it may be affected by geopolitics and regional conflict.

Our argument in brief is that developments in consumption volumes and patterns will be most important. Market forces are vital, but they are influenced by power, politics and public policy outcomes. Transportation is the most important sector for oil consumption; changes in transport behavior, modes and technology will therefore be vital drivers. The behavior of investors will be a decisive factor in shaping the production side of the oil system. If investments go down as a response to lasting low oil prices, and/or because investors decide to turn to green economy options, then the supply of oil will logically shrink. On the other hand, the growth and development aspirations of a rapidly growing population in developing countries are likely to stimulate demand, and thus increase exploration, production and subsequently the price. Finally, we emphasize the importance of (geo)politics that are influencing all aspects of the value chain of oil.

\section{Oil as Part of the Global Energy System}

The target set by the Paris Agreement, to keep the increase in the average global temperature well below 2 ${ }^{\circ} \mathrm{C}$ above pre-industrial levels, is demanding. If the target is to be met, radical changes in the global energy system are required. Moreover, key actors also have to change their policy with regard to both adaptation and mitigation measures.

In order to evaluate the impact of the Paris Agreement on energy sectors, it is important to acknowledge some fundamental features of that system. One such feature is that energy sources are not equivalent in all respects, nor are their users. Put simply, the idea is that we have some primary energy sources that we want to turn into various energy services, such as the heating of rooms and water, the cooking of food and the cooling of beer, locomotion, or lighting. In addition, some primary energy sources are used as input factors in industrial production. This goes particularly for oil, which is a key factor in the production of several thousand consumer products. Between the primary energy sources and the energy services, we find what is usually called secondary energy. In the case of oil, these are the various refined petroleum products, such as gasoline, diesel and jet fuel. Electricity is another kind of secondary energy that is particularly flexible, since it can be produced from several of the primary sources and used for most of the energy services. The primary energy sources are usually categorized as fossil fuels (crude oil, natural gas and coal), nuclear fuels (uranium and possibly thorium) or renewable energy (water, sun, wind, tide, biomass and geothermal energy).

The distribution of world consumption of primary energy in 2013 is shown in Table 1 . However, the distribution of primary energy does not necessarily reflect the importance of the various primary sources in the end use, or in energy service provision, since the energy efficiency and losses of the different primary sources varies with the different technologies for transferring the primary source into the various energy services.

Table 1 also includes the scenarios of the International Energy Agency (IEA). These are not to be taken as predictions, but rather as descriptions of possible future developments. In the Current Policies scenario, only policies for which implementing measures are formally adopted are included. In the New Policies scenario, relative intentions announced are also included. This is the central scenario of the IEA. The 450 Scenario attempts to capture the necessary measures in order to limit the rise in global temperature to two degrees Celsius (IEA, 2015, pp. 34-35).

Technological innovations are essential drivers for increased efficiency and reduced losses in the whole value chain. Technological revolutions do occur, but they are hard to foresee and thus not included in any of the IEA scenarios in Table 1 . In the transportation sector, there is ongoing research regarding both the vehicles and engines, and the use of various new fuels, such as hydrogen. More incremental technologyimproving processes have been taking place for a long

Table 1. World primary energy consumption in 2013 and IEA scenarios in million tons of oil equivalents (mtoe). Source: IEA (2015, p. 57).

\begin{tabular}{lrrrr}
\hline & & Current Policies & New Policies & $\mathbf{4 5 0}$ Scenario \\
\hline Year & $\mathbf{2 0 1 3}$ & $\mathbf{2 0 4 0}$ & $\mathbf{2 0 4 0}$ & $\mathbf{2 0 4 0}$ \\
\hline Coal & 3,929 & 5,618 & 4,414 & 2,495 \\
Oil & 4,219 & 5,348 & 4,735 & 3,351 \\
Gas & 2,901 & 4,610 & 4,239 & 3,335 \\
Nuclear & 646 & 1,036 & 1,201 & 1,627 \\
Hydro & 326 & 507 & 531 & 588 \\
Bioenergy & 1,376 & 1,830 & 1,878 & 2,331 \\
Other renewables & 161 & 693 & 937 & 1,470 \\
\hline Total & $\mathbf{1 3 , 5 5 8}$ & $\mathbf{1 9 , 6 4 2}$ & $\mathbf{1 7 , 9 3 5}$ & $\mathbf{1 5 , 1 9 7}$ \\
\hline Fossil fuel share & $\mathbf{8 1 \%}$ & $\mathbf{7 9 \%}$ & $\mathbf{7 5 \%}$ & $\mathbf{6 0 \%}$ \\
\hline
\end{tabular}


time, e.g. with the combustion engine (Jacobs, 2015).

The importance of the different primary energy sources in the various consumption sectors differs from country to country. Although oil constitutes approximately one-third of primary energy consumption, it is not used in all end-user sectors. Table 2 illustrates the variation in primary energy consumption for the US, China, India and the EU. These four constitute $56 \%$ of total world energy consumption.

The fossil fuel share is more than $70 \%$ in all four countries, although the fossil mix is different, with China having two-thirds of its energy consumption met by coal, compared to the US and the EU, where this share is less than one-fifth. These four actors will be quite decisive if the Paris goal of "well below $2{ }^{\circ} \mathrm{C}$ " is to be achieved. Their Indicated Nationally Determined Contributions (INDCS) vary considerably, with the EU's binding target of an at least $40 \%$ domestic reduction of greenhouse gas emissions by 2030 compared to 1990 being by far the most ambitious. China aims to achieve the peaking of carbon dioxide emissions by around 2030, and to increase the share of non-fossil fuels in primary energy consumption to approximately $20 \%$ (versus $12 \%$ in 2013). The US' commitment is a $17 \%$ reduction by 2020 (from the 2005 level of emissions) and to explore possible accelerated reductions further on, whereas India has committed itself to a $20-25 \%$ reduction over the same period. These policy positions combined are not going to result in implementing the "well below $2{ }^{\circ} \mathrm{C}$ " target. The procedure of setting more ambitious targets every five years, and developing a transparent and accountable system to follow up Paris and the five-year revisions, is therefore crucial.

\section{Oil Consumption by Sector}

Figure 1 shows the distribution of global oil consumption by end-use sectors in 2014 and the IEA's central scenario for 2040. According to the so-called New Policies scenario, three-fourths of oil consumption in 2040 will be used for transportation and petrochemicals. Hence, our discussion will focus on some of the possibilities and obstacles for change in these two sectors.

Table 2. Primary energy consumption in 2013 (mtoe and percentage). Source: IEA (2015, annex).

\begin{tabular}{lrrrrrrrr}
\hline & & US & & EU & & China & India \\
\hline Coal & mtoe & \% & mtoe & \% & mtoe & \% & mtoe & \% \\
Oil & 432 & 19.8 & 286 & 17.6 & 2,053 & 67.6 & 341 & 44.0 \\
Gas & 782 & 35.8 & 513 & 31.6 & 483 & 15.9 & 176 & 22.7 \\
Nuclear & 610 & 27.9 & 387 & 23.8 & 142 & 4.7 & 45 & 5.8 \\
Hydro & 214 & 9.8 & 229 & 14.1 & 29 & 1.0 & 9 & 1.2 \\
Bioenergy & 23 & 1.1 & 32 & 2.0 & 78 & 2.6 & 12 & 1.5 \\
Other Renewables & 97 & 4.4 & 140 & 8.6 & 216 & 7.1 & 188 & 24.3 \\
Total & 26 & 1.2 & 37 & 2.3 & 37 & 1.2 & 4 & 0.5 \\
Share of world total & 2,184 & 100.0 & 1,624 & 100.0 & 3,038 & 100.0 & 775 & 100.0 \\
\hline
\end{tabular}

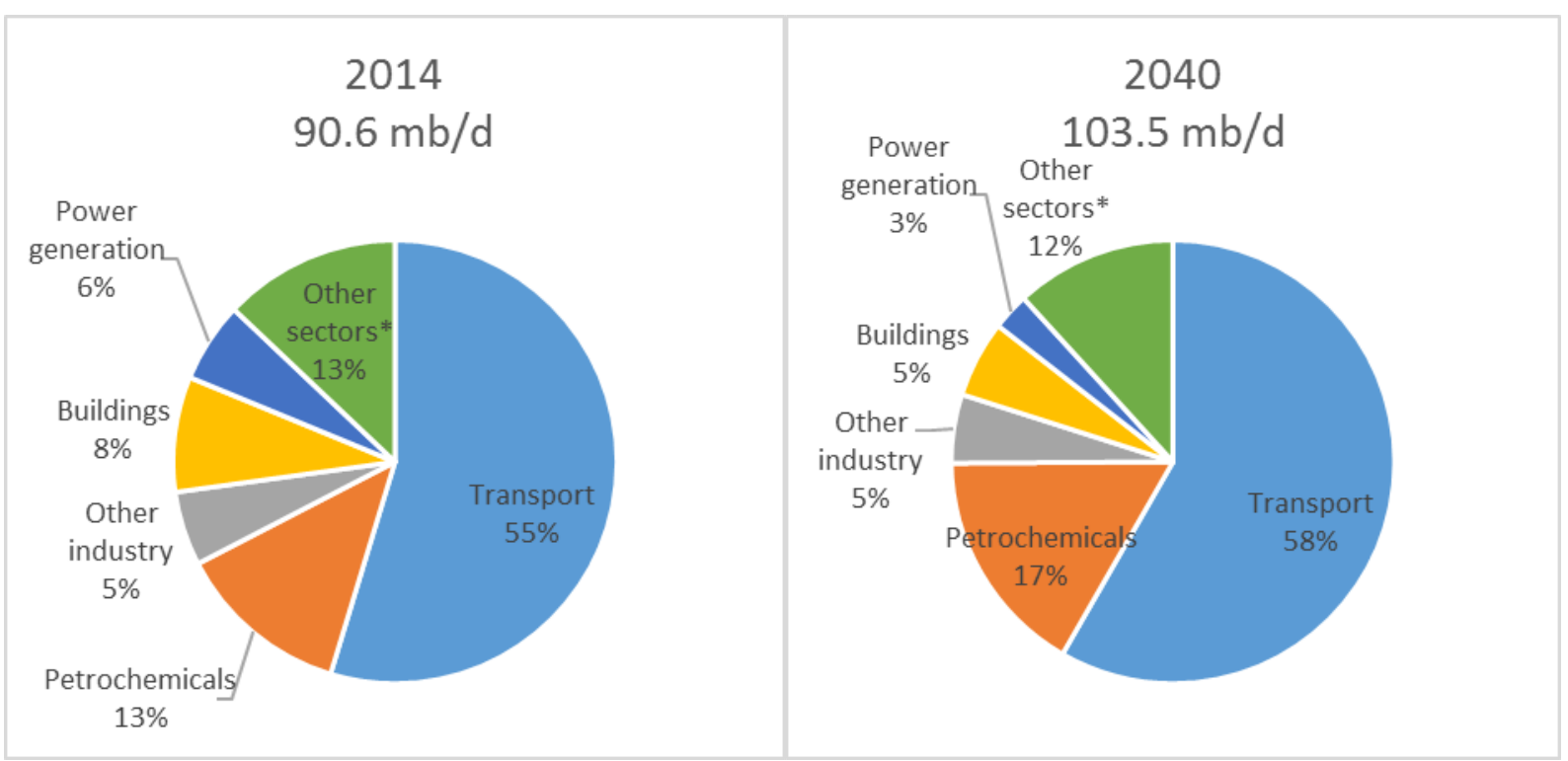

Figure 1. Global oil consumption by sector, 2014 and 2040 (New Policies scenario), million barrels per day. Source: IEA (2015, p. 121). Note: * Includes agriculture, transformation and other non-energy use (primarily bitumen and lubricants). 
One obvious option is to disconnect emissions from use, in other words to capture the carbon before being released into the atmosphere (Carbon Capture and Storage-CCS). Although this can be important for industrial oil use, applying CCS technology to mobile emission sources seems unrealistic today. The attention of CCS has been more prominent in power generation than in the industry sector, due to the fact that reducing power generation from coal and natural gas could be one of the most important ways of reaching global emission targets, while the oil-based industry is less prominent. Oil has almost been phased out as a source for power generation (cf. Figure 1). Thus, CCS in power generation will in itself hardly affect the global oil market. However, successful CCS in power generation could even influence the industrial sector, and therefore also the oil market. Thus far, the costs of CCS have prohibited large-scale introduction in both power generation and the industrial sector.

A second option, both in transport and industry, is to improve the efficiency of installations, production plants and vehicle engines. As mentioned above, oil is part of the production of goods used in the industry sectors itself, in building materials and in thousands of consumer products. These many products are made by the application of a number of different technologies and production processes. It follows that "a piecewise approach to reducing emissions is required, which is challenging to monitor, incentivize and control" (Brown, Gambhir, Florin, \& Fennel, 2012, p. 1). Furthermore, the current industrial technological standard varies immensely across countries and regions. As a result, technology transfer will both increase efficiency and reduce emissions. Nonetheless, improved energy efficiency can have unintended consequences regarding consumption. If buying a more fuel-efficient car leads to increased driving, the positive effect on emissions is reduced (Sorrell, 2007). This is further complicated in the transportation sector, since there is no linear relationship between high income and reduced emission. With a high income, two effects follow: a larger car, with a more gasoline consuming engine, and more cars in the same household. These effects can nullify the effect of technological improvements in the car engines themselves.

A third possible strategy is to switch from fossil fuels to renewables. In the industrial sector, this will be a matter of costs and profit margins. In most cases, changing fuel in existing industrial plants seems to be prohibitively costly, at least without government subsidies. Building new plants with non-fossil input will depend on investments in new technology, but without any subsidies such investments will have to pay off in companies' balance sheets within a reasonable time frame. In the transport sector, there are major challenges to accomplish a total fuel switch. The most readily available alternative at the end-user stage is to switch from a fossil fuel car to an electric car. The US National Academy of Sciences discusses this issue in a large-scale report entitled, Hidden Costs of Energy. They balance the externalities of a reduction in urban emissions, safety issues and the environmental aspects related to battery recycling and disposal. They find that the positive impact of fuel switching in the consumption stage of the value chain depends on the type of primary energy fed into the electricity production. If coal is used to generate the electricity used in electric vehicles, the emission reduction from replacing the internal combustion engine with the electric engine is reduced and possibly lost, also if considering the efficiency gains in the engine: "when the damages attributable to other parts of the life cycle were included, especially the emissions from the feedstock and the fuel (emissions from electricity production), the aggregate damages for the grid-dependent and all-electric vehicles became comparable to, or somewhat higher than, those from gasoline" (NAS, 2013, p. 202). The net benefit of the electric car is a highly controversial issue, and solving it is far beyond the scope of this article.

Finally, the underlying trends in demand will also influence the possibility of reducing overall global oil consumption. For the industry sector, the IEA finds that, "Despite the growth in total demand, the oil intensity of GDP (i.e. the amount of oil used per unit of economic value) continues to decline.... The industry sector, the second-largest contributor to global GDP and the second-largest oil consumer (when including petrochemical feed stocks), uses $30 \%$ less oil per unit of value added [than one and a half decade ago]." This effect is slower in the industry sector than in the service sectors because "soaring demand for plastic products in developing economies more than offset further improvements and saturation effects in the industrialized countries" (IEA, 2015, p 120). In the transportation sector, a number of factors will influence the future demand for the various fuels. Although the average fuel consumption, and thus emissions, of new passenger cars is likely to continue to fall, consumer choices may offset the effect on total emissions as the number of cars increases (cf. Figure 2). Also note that in 2005 the number of new cars sold in China was 33\% of the number sold in the US, and that by 2015 the same ratio had increased to $140 \%$. The number of vehicles in use in 2014 was 808 per 1,000 inhabitants in the US, 569 in the EU, 102 in China and only 22 per 1,000 inhabitants in India (OICA, 2015). From 2013 to 2014, the share of electric vehicles grew from $1.3 \%$ to $1.5 \%$ in the US, and from $0.1 \%$ to $0.3 \%$ in China. We predict that the car industry will move strongly into non-fossil car production over the coming decades, and that both electricity and hydrogen will represent competitive alternatives to fossil fuel cars.

The hardest obstacle to achieving a reduced global consumption of fossil fuels is the fact that for several decades many hundreds of millions of people will in- 
crease their energy consumption. Table 1 suggests an increase in the use of all types of primary energy sources, although renewables represent the strongest growth. It nevertheless leads to a fossil fuel share in the global energy mix in 2040, even in the best climate scenario, of $60 \%$.

Within these global trends, there are important geographical differences that reflect variations in the level of industrialization and economic development. Countries and regions that are relatively industrialized and economically developed will reduce oil demand, whereas those which are still relatively less industrialized, and with populations aspiring to economic development, will likely increase their demand for oil (Figure 3). The Paris treaty takes unequal levels of development into account by not committing developing, in particular the least developed, countries to combatting
GHG emissions to the extent that developed countries are committed. Implementation of the agreement will "reflect equity and the principle of common but differentiated responsibilities and respective capabilities" (Agreement art. 2). A major political issue in the years ahead will therefore be how to balance global goals for combatting GHG with national aspirations for economic development. In this issue area, China and not least India, with its combination of demographic growth and high economic growth potential, will be key actors. For both these countries, however, the vital factor in determining their follow-up of Paris is their consumption of coal (see Table 2). There is a considerable amount of potential for energy conservation in the carbon sector in China, but it is very much dependent on an increased investment in innovating and developing new technology (Boqiang \& Xuan, 2015).

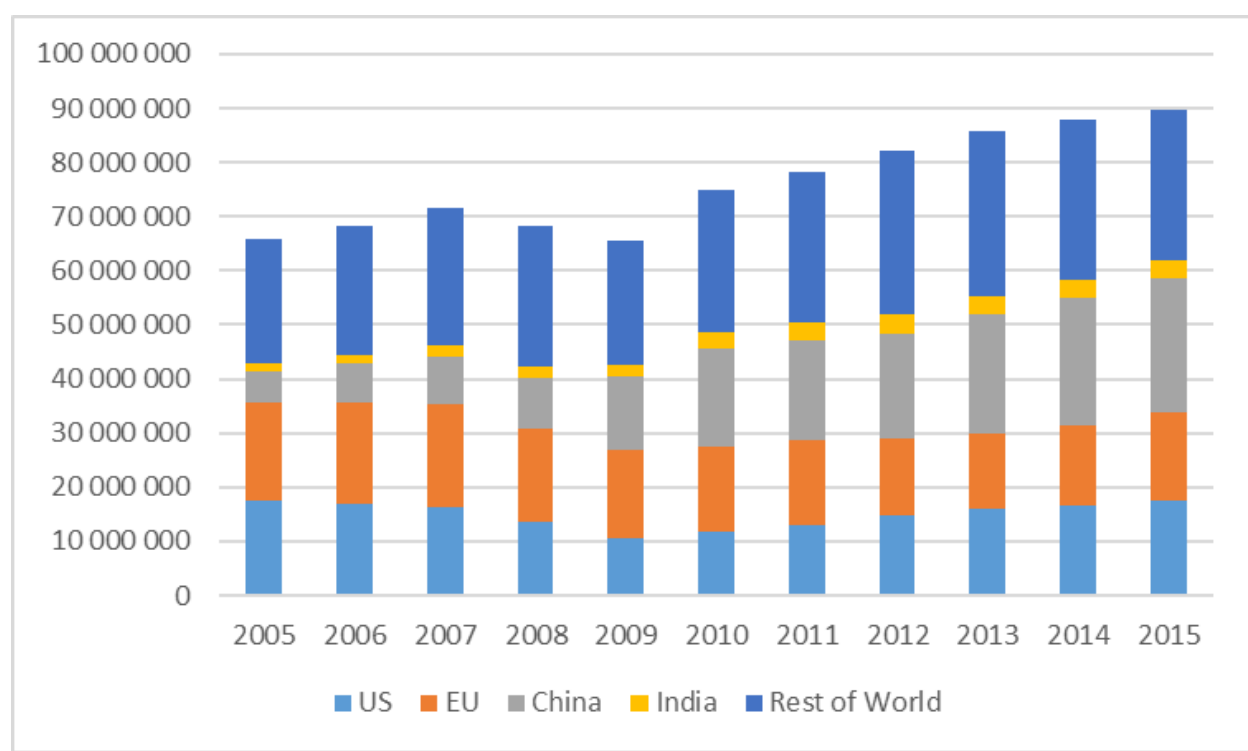

Figure 2. Registration or sales of new vehicles 2005-2015. Source: OICA (2015).

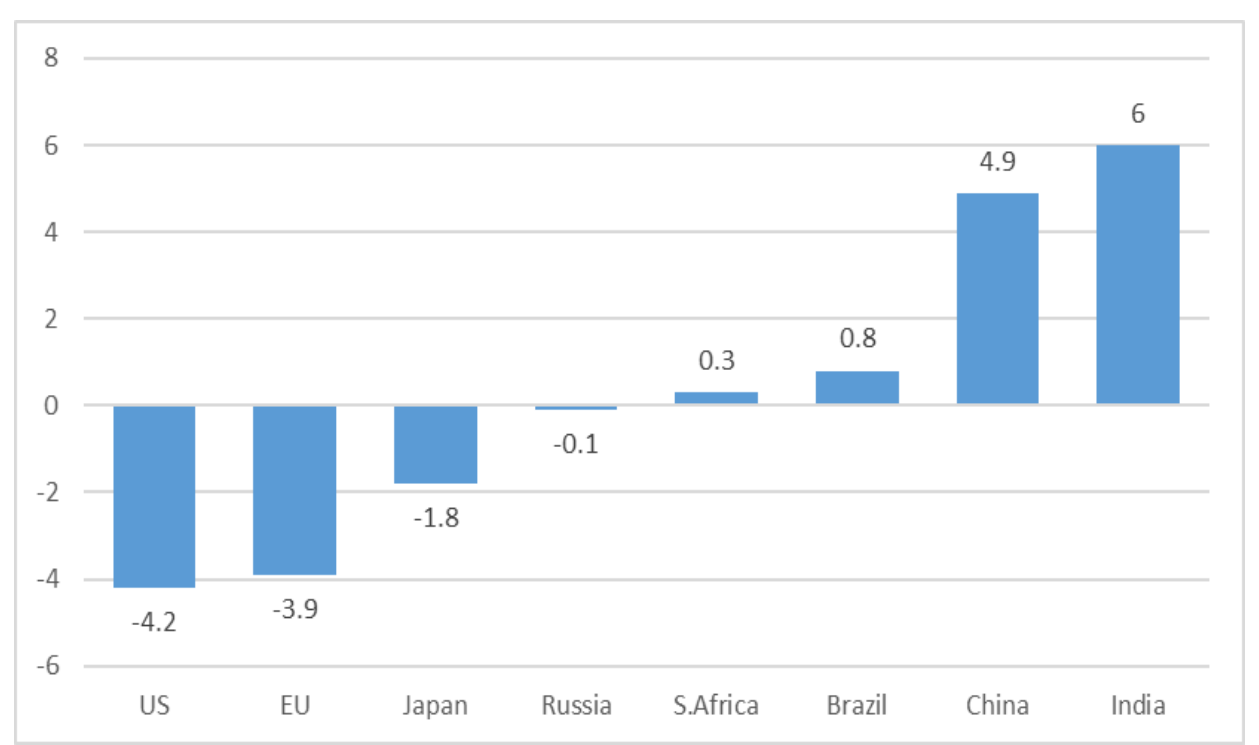

Figure 3. Change in oil demand in selected countries and regions in the New Policies scenario, 2014-2040. Source: IEA (2015, p. 467). 
There are billions of oil consumers making individual decisions and calculations every day with implications for global oil consumption. The implementation of the Paris Agreement will have to put in place various incentives, restrictions, regulations and legislation all over the world for these individuals to reduce their oil consumption. A large number of the oil-consuming individuals live in countries that provide them with a significant degree of freedom regarding their choices of energy consumption. In these cases, changes are best induced through mild incentives or changes in attitudes toward oil consumption at the societal-, and not least the local level.

\section{Counterforces: Producer Reactions}

The structure on the producer side of the market is different from that on the consumer side. Compared to the billions of individual oil consumers, the top 10 producing countries cover two-thirds of the market (cf. Table 3), which obviously represents considerable power.

All of the top 10 producers, with the exception of the US, have a strong state involvement and control over their oil industry, and thus all decisions related to oil production, and subsequently the market-related reactions to the implementation of the Paris Agreement. Although there are important differences between Canada, Saudi Arabia and China regarding governmental control, we argue that the economic aspects relevant for analyzing their reaction to Paris will be fairly similar.

Most of the largest oil producers were against any type of international climate agreement, simply because it increases the likelihood of a reduced consumption of oil. Some producer countries were more active in their opposition to the Paris treaty than others, with reports suggesting that Saudi Arabia was particularly active.

We will not discuss these aspects further here, instead focusing on the options available to oil-producing countries in the face of an increased potential for nontrivial negative effects on oil consumption following from the Paris conference. The conclusion of the previous section was that such effects are hard to identify in the short run, but they might be more likely in the long- er run. It should also be noted that the Paris Agreement can create significant emission reductions without having a strong impact on the oil sector, for instance if the global coal consumption is reduced considerably.

Even so, it is fair to expect some kind of strategic reaction from oil producers, based on the fact that the Paris Agreement has created a new type of uncertainty for their long-term reliance on income from oil exports. Saudi Arabia's intention to diversify into financial operations is an illustration, though probably a non-typical one given the country's extraordinarily strong position as the world's largest oil exporter. When it comes to options related to the market and the oil industry of producing countries, we see three possible strategies to meet reduced demand induced by the Paris Agreement:

Competitive strategy: In this case, the oil producers meet the competition from other energy sources by reducing the price of oil. On average, the production costs in countries like Saudi Arabia and the other Gulf states are less than 10 US dollars per barrel. More important in the oil industry is the so-called replacement cost (the cost of replacing a consumed barrel with a new barrel), which represents the long-term costs of sustaining current production levels. The figure has been falling every year over the last three decades, but with some exceptions. The technical and industrial potential for a long-term/low-price strategy is present. However, to what extent it is economically and politically viable is less obvious, and if the alternative is to be out of business, several key producers might find this strategy attractive. With moderate investments, several of the producers around the Persian Gulf can increase their production capacity (OPEC, 2015).

Capitulation strategy: Models of resource economics suggest that oil-producing countries do not operate according to principles of market economics, but instead try to gain as much rent from their respective oil wealth as possible (Dasgupta \& Heal, 1979; Hotelling, 1931). If the expectation is that the consumers will turn away from oil in the long term, it could make sense to try to gain as much money as possible from the oil reserves, as soon as possible. This would imply immediately dumping as much oil as possible on the market.

Table 3. Top 10 oil producers. Source: BP (2015) and World Bank (2016a).

\begin{tabular}{lrr}
\hline Country & Share of world production (2014) & Oil share of GDP (2014) \\
\hline US & 13.1 & 0.8 \\
Saudi Arabia & 13.0 & 38.7 \\
Russia & 12.2 & 12.7 \\
Canada & 4.8 & 3.4 \\
China & 4.8 & 0.9 \\
UAE & 4.2 & 19.0 \\
Iran & 4.1 & 23.6 \\
Iraq & 3.7 & 41.4 \\
Kuwait & 3.5 & 57.7 \\
Mexico & 3.1 & 6.8 \\
\hline
\end{tabular}


This would obviously bring the price down, so it is not entirely distinct from their competitive strategy, but it can be identified by the oil producers, thereby maximizing their production according to their installed production capacity and, if possible, to increase their production capacity even further.

Change-over strategy: This strategy moves us away from the pure market operations, and focuses on alternative courses of action in order to sustain current economic welfare levels. Several of the Middle East oil producers have pursued such a strategy for decades, though with little success. It is very difficult to turn resources and investments away from an extremely lucrative industry, such as oil production in the Middle East, into necessarily less lucrative sectors. A fall in oil prices might help such a strategy. Another aspect emerging is that some of these countries have natural conditions for alternative energy production, first and foremost solar power. It would obviously not be possible to replace the income from oil in the short run. But it is possible to imagine a breaking point, in which the long-term value of solar power, investment costs included, outweigh a losing battle to sustain world oil demand by cutting oil prices.

The three strategies are not that distinct from each other, but they can be empirically identified by investigating market behavior, production level and capacity change, as well as investments in alternative industries. Still, these factors can change even without any reference to the Paris treaty or climate change in general. Since 2014, the market behavior of the leading producer country, Saudi Arabia, has seemingly changed dramatically, from sustaining a high price to instigating a price war against high-cost producers outside of OPEC. On closer inspection, however, the Saudi Arabian policy is not new. It is in line with the behavior of the Kingdom in 1985-86, when the attempt to sustain the high prices created in the 1970 s by cutting production failed. It then flooded the market in order to drive high-costs producers out of business. The high price of oil from 2008 to 2014, combined with technological breakthroughs in the production of so-called shale oil, has attracted new producers, in particular in the United States. The market became oversupplied, and the price started dropping in the autumn of 2014. This time Saudi Arabia did not cut its own production, but instead increased it in order to reduce the profitability for all high-cost producers.

The immediate motivation behind this strategy is not directly linked to climate change or the Paris treaty. Even so, the ambition for oil producers with large resource bases to prolong the horizon of the oil age can influence the likelihood and costs of replacing the consumption of fossil fuels with renewables. An oil price above $\$ 100$ per barrel would make it much easier for renewables to compete than with an oil price below $\$ 50$ per barrel. The available resources that can be produced profitably at $\$ 20$ per barrel over the next decades are almost infinite.

For some of the key oil exporters, the income from oil exports is crucial for their economic activity in general, and thus for the welfare level of their societies (cf. Table 4). In addition, some of these countries are socalled rentier states (Luciani, 1990; Noreng, 2004), indicating that the state is economically independent of its inhabitants as it supports itself from oil income. In such cases, a reduction in oil income jeopardizes the political leadership. For instance, the Saudi Arabian regime appears to be dependent on distributing parts of its oil income among a population that is widely unemployed (Cappelen \& Choudhury, 2004). At the same time, it has a huge potential for defending its position, illustrated by its announcement to register ARAMCO, the state oil company, and by far the biggest producer in the world, at the Riyadh stock exchange. Selling a mere $5 \%$ of the company will raise $\$ 250$ billion and support state finances currently running a budget deficit. In other words, the Kingdom disposes of a huge reserve of not only oil, but also financial resources that could make it not only invulnerable to financial problems, but also diversify its economy and make it less dependent on oil income in the future.

Table 4. Top 10 crude oil exporters. Source: World Bank (2016b).

\begin{tabular}{lrr}
\hline Country & Oil exports $(\mathbf{m b} / \mathbf{d})$ & Share of total exports (\%) \\
\hline Saudi Arabia & 6,250 & 76 \\
Russia & 4,871 & 68 \\
Canada & 2,470 & 19 \\
Iran & 2,297 & 54 \\
United Arab Emirates & 2,181 & 28 \\
Nigeria & 2,115 & 92 \\
Angola & 1,909 & 90 \\
Iraq & 1,903 & 99 \\
Venezuela & 1,594 & 96 \\
Kuwait & 1,495 & 94 \\
\hline
\end{tabular}




\section{Pursue Paris or Protect Profits? Investor and Company Reactions}

Investor decisions are a crucial factor in shaping the effects of Paris. Private investment decisions are also crucial to the prospect of sustained oil production in most producer countries, with the possible exception of several key producers in the Middle East. While the rig count of Saudi Arabia increased 15\% from 2014 to 2015, it was almost cut in half in the US (OPEC, 2016, p. 91). If investments in the oil industry were to dry up, the industry would also contract. At the moment (Spring, 2016), the price of oil is naturally a focal point for investors. With low prices, the time horizon will have to be extended in order to handle risk and gain lifetime profits from the individual field investments. Nonetheless, we argue that price developments are not the only factor to consider when the future behavior of investors and companies is analyzed.

Contrary to the oil producers themselves, the investor can rapidly change from oil to other assets. The role of investors, whether they sit inside the producing companies, provide capital to finance those companies or the oil services companies, or whether they consider investing in transportation modes, has an effect at all stages of the oil value chain. In many countries, oil production is a capital-intensive business. Therefore, a crucial variable in the premises forming investor decisions is what long-term strategies they adopt, among other things what time horizon they apply for their profit target and what risk they are prepared to take. The coal industry is already subject to substantial disinvestment. Moreover, several individual investors, as well as corporate managements, have signaled that they will invest in the transformation to a green economy. However, the standard assumption is that most investors still respond primarily to market forces, and their own profit aspirations and risk assessments rather than to Paris. Will this change, and thus give Paris a significant impact on investors' behavior?

Current trends could be a signal. At the current price level ( $\$ 40$ per barrel), producer companies lose money on drilling for oil in the United States and most, if not all, offshore global locations. They "are slashing jobs, costs and capital spending in order to maintain promised dividend payouts. But the lower prices go, the more they borrow to honour those pledges" (The Economist, 2016b). The 400 largest oil service companies have slashed 250,000 jobs since 2014 (Ånestad \& Haug, 2016). Several of the major Western companies piled up debt in 2015, and some have been downgraded by the rating agency, Standard \& Poor's. An increasing share of corporate bonds is trading on negative yields, and investors are losing money. The proportion of junk bonds deemed to be distressed more than doubled from early 2015 to 2016, with the oil and gas sector accounting for the biggest share of issuers in dis- tress, at $30 \%$ of the total (The Economist, 2016a). Although the default rate is still below the historical average, it doubled from the low of 2014, and will likely continue to rise if the price of oil does not.

The downward trend is also reflected in investments. Hence, global investments in oil fell from $\$ 920$ billion in 2014 to an estimated $\$ 620$ billion in 2016. At the same time, investments in green energy have been larger for the last four years than in the entire carbon sector. Green investments have increased six-fold from 2004 to 2015 (Mathismoen, 2016). Consequently, there is a possibility that investors will decide to move out of all fossil fuels, and not only coal. These trends are clear signals, but should at this point still be seen as indications of change, and not proof that an irreversible change has started. It is, however, a clear indication of change that the one-third drop in investments started before Paris. On the other hand, the past is a story of very volatile oil prices; and some investors may bet on that pattern repeating itself. A good number of them are expecting price increases in the months or years to come; they may rely on the consultancy firm Rystad Energy, which predicts a price rise to above $\$ 100$ by 2020 (Melberg, 2016). Some of them may even decide to invest in exploration, but maintain the option to withdraw the investment later if the success of operations looks unpromising. ${ }^{1}$

The Western majors, the International Oil Companies (IOCS) that ruled the oil industry for several decades, are no longer in a position to do so. Since the 1970s, they have lost control over primary oil production and reserves, and they have also lost some of their control over oil technology to service companies. Their response has been to diversify, notably into gas, thereby merging and maximizing shareholder value. Gas, however, is a competitive market, in which the IOCs are neither dominant nor necessarily the most competitive. And as we demonstrated above, shareholders appear to be becoming as concerned about current cash flow problems and increasing debt as they are about making new investments. As Paul Stevens argues, the whole business model of the IOCs is faltering; as they have adapted too late to the changing technology and geopolitical shifts (Stevens, 2016). At the same time, we submit that the IOCs, perhaps because they are struggling to maintain their global position and their business model, may attempt to compensate for their losing power at the international level by exercising pressure and power at the domestic level. This appears to apply in particular to the US, where the president's policy decisions may be blocked by Congress. If the IOCs want to block Paris, this is arguably their best chance of doing so. Having said this, we also observe that some of the IOCs like Shell have set a strategy that

\footnotetext{
${ }^{1}$ For a modelling of this and alternative decision-making options, see Begg, Bratvold and Campbell (2002).
} 
implies that they plan to take part in the greening of the energy system.

\section{Contextualizing the Issue: Geopolitics or Paris?}

Periodically, political, in particular geopolitical factors, have had a strong influence on the price of oil (Favennec, 2007; Painter, 2014). Major wars or political revolutions in major producer countries almost automatically lead to greatly increased oil prices, while a peaceful resolution to a major conflict lowers prices. Abrupt changes in political regimes also have a proven effect on prices. Security, including energy security, has traditionally been and will continue to be a serious concern for governments. These factors have either trumped market factors to set them aside, or they have boosted them. In both cases, the result has been upwards or downwards price fluctuations (cf. Figure 4), and there is nothing to indicate that these factors will have less importance in the future.

Predicting geopolitics and its effects is almost as difficult as predicting the price of oil-of which geopolitical events are also major drivers. Together with the reintegration of Iran in the oil market after the nuclear deal, the current conflict between Saudi Arabia and Iran has led to an increased supply. Due to the geopolitical interests of Saudi Arabia overriding the economic interests of re-establishing the producer alliance, the Doha meeting in mid-April 2016 ended without an OPEC agreement to regulate volume (Raval, Sheppard, \& Hume, 2016). Changes in the regional security complex of the Middle East, and more specifically the Persian Gulf, will continue to influence the market behavior of the oil suppliers inside the region. It will also continue to be an important factor in the foreign policy of the superpowers. The evolution of the relationship between the United States and China will likely affect the demand for oil; if they stay relatively cooperative they will not drive demand, but if they were to turn towards more conflict, for instance over East Asian security issues, these powers are likely to increase efforts to guarantee their own energy security. National security may trump international compliance to climate policy, and Realism trumps Institutionalism.

This may result in various types of policy, ranging from measures at home to action at the international level. Increased self-sufficiency in primary energy would imply measures such as an increased stocking of supplies and less emphasis on the cost of production at home. It may also mean diversifying energy usage and supply channels, including foreign ones and to try and obtain better control of them (Tunsjø, 2013). The major powers will even attempt to control exogenous supplies to their geopolitical competitor(s) by influencing their suppliers, control transportation lines or by other means. An increased emphasis on energy security may also imply that nuclear power as a primary energy source may become reinstated.

History offers several examples of the rationing of secondary energy usage being introduced during periods of war or major international conflicts, with the purpose of diverting energy usage from civilian to military-related applications. Such motives might still be important, but the most likely net effect of increased geopolitical conflicts is to halt or stop GHG measures following from the Paris treaty. The countries likely to be involved in geopolitical games are also the major oil consumers and/or producers.

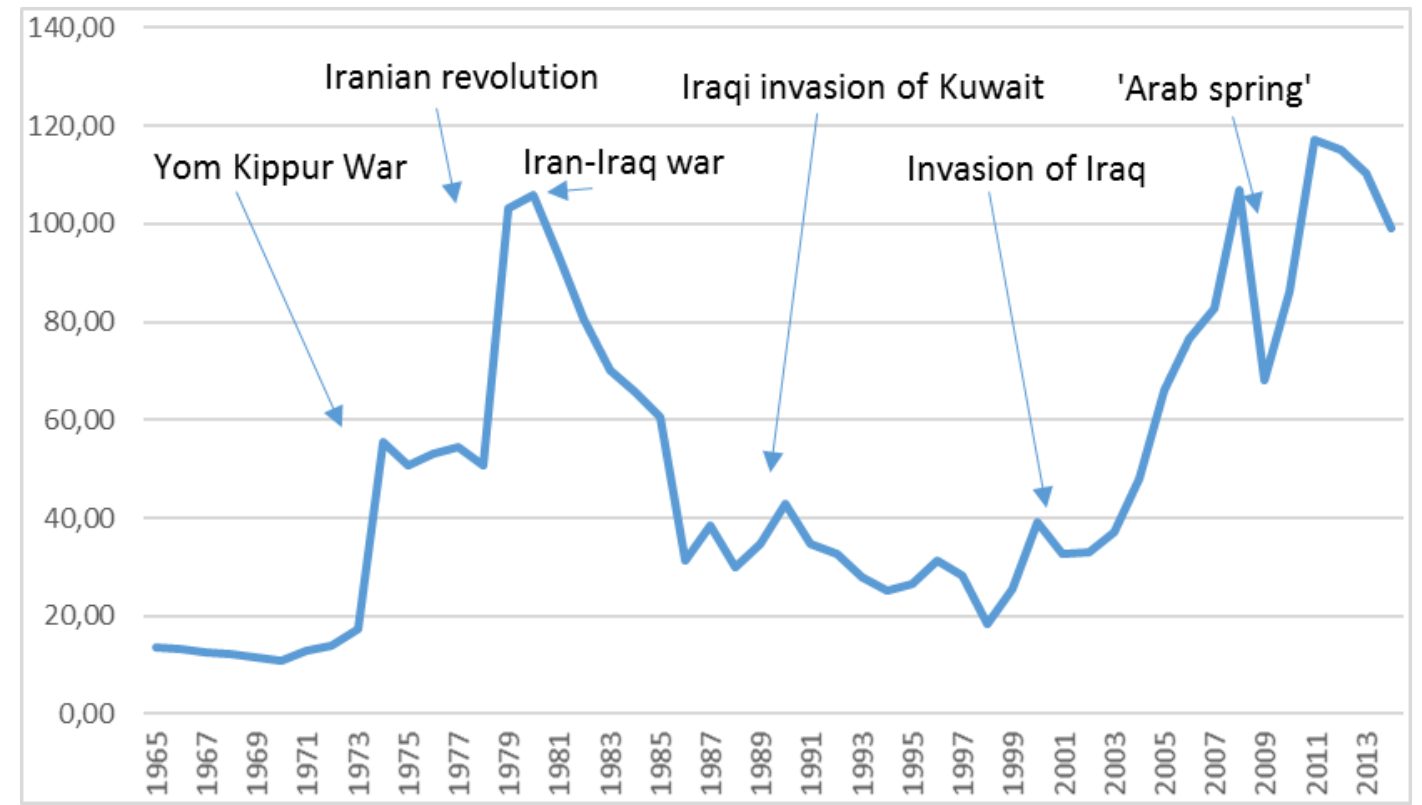

Figure 4. Oil price (\$2014 per barrel) and political events. Source: BP (2015). 


\section{Summary and Conclusion}

The Paris treaty is a major political and institutional achievement. However, its effect on the global oil system is uncertain and complex. The casual chain leading from Paris to the end of oil is long, and subject to a number of intervening factors. Even if consumers and investors also push for de-carbonization regarding oil, producer countries and the oil industry might contradict such efforts. How strong and how general the Paris effect will be on oil is therefore extremely difficult if not impossible to predict.

This article has discussed several factors that may impact on the outcome, some in support of the Paris agreement and others working against it, and yet others with an uncertain or neutral effect. The agreement's key principle of burden-sharing, that countries have a Common But Differentiated Responsibility (CBDR), offers flexibility in implementation and therefore also uncertainty regarding the end result. With this complexity and variety in mind, we presented scenarios for how Paris might affect different parts of the global oil system:

- Without a substantial effect on the global consumption of fossil fuels (oil, gas and coal), the Paris treaty will be a failure. Oil is probably the hardest to eliminate since the technological alternatives in the transportation sector have not been fully developed thus far. De-carbonizing oil consumption implies not only a switch of power source from oil to hydrogen or electricity, but also new motors, cars, ships, airplanes and new infrastructure in most parts of the transportation sector. Such changes might be both induced and reduced by the interests and attitudes of the world's billions of energy consumers. It may obviously also be influenced by powerful commercial actors. In democratic countries, the attitude of the electorate will strongly influence the pattern and speed of change. On the international political scene, individual countries are reluctant to move ahead of other countries in introducing costly taxation or climate programs, for fear of losing competitiveness. In certain cases, domestic public opinion can override such fear. Rich countries are in a better position to take on risky climate policies than poor countries, and democratic consuming countries are more likely to experience such a domestic pressure than autocratic regimes, although it should be mentioned that recent changes in the Chinese energy policy are assumed to be the result of strong public opposition to local environmental degradation from, inter alia, coal-fired power plants.

- We emphasize the role of investors. Their behavior is an early warning of the future, an economi- cally viable course, and that the energy transition may follow. Investments are essentially an attempt to spend money today in order to earn money tomorrow. If the de-carbonization of the energy system is becoming profitable, we should expect to see a move in investments from fossil fuels to renewables, including in technologies, production, infrastructure, end-user facilities and so on. Decisions by risk-aversive investors outside of the oil industry increasingly follow the latter, and have a large overall effect on the industry. In the most likely variant of this scenario, investors continue to move out of oil in the expectation of continued uncertainty about future profitability. In the case of oil, such an observation is distorted today as investors are moving away from oil, but most likely due to the relative low oil price that emerged in 2015.

- The most compelling counteracting factor in this picture is the response to changes in consumption by the key oil producers. We developed three possible producer strategies with the following implications: producers with low costs of production follow a competitive or capitulation strategy, while facing the prospect of continued prices below profitability, many of those producing at higher costs will pursue the change-over strategy.

- We also see politics as an intervening factor among the producers. Geopolitically motivated competition and rivalry, as well as radical political regime changes, create periodic price changes. Historically, they have mostly resulted in price increases that induce rival producers and investors to remain in oil. In the case of the current geopolitical competition in the Middle East between Iran and Saudi Arabia, the result is an increase in volume that has led to a price drop. Unfortunately, this has resulted in a price drop that, at least from a climate emissions point of view, makes oil more competitive for energy consumers.

\section{Acknowledgments}

The authors wish to thank Aslak Brun, Dag Anders Dyrdal and two anonymous reviewers for their helpful suggestions and comments.

\section{Conflict of Interests}

The authors declare no conflict of interests.

\section{References}

Ånestad, M., \& Haug A. M. (2016, February 14). Oljekjempene banker på døren. Dagens Næringsliv.

Begg, S., Bratvold, R., \& Campbell, J. (2002). The value of flexibility in managing uncertainty in oil and gas in- 
vestments. Paper presented at Society of Petroleum Engineers Annual Technical Conference and Exhibition, September 29-October 2, San Antonio, Texas.

Boqiang, L., \& Xuan, X. (2015). Energy conservation potential in China's petroleum refining industry: Evidence and policy implications. Energy Conservation and Management, 91, 377-386.

BP. (2015). Statistical review of world energy, June 2015. Retrieved from http://www.bp.com

Brown, T., Gambhir, A., Florin, N., \& Fennel, P. (2012). Reducing $\mathrm{CO} 2$ emissions from heavy industry: A review of technologies and considerations for policy makers (Briefing paper no. 7). London: Grantham Institute for Climate Change, Imperial College.

Cappelen, A., \& Choudhury, R. (2004). The future of the Saudi Arabian economy: Possible effects of the world oil market. In D. Heradstveit \& H. Hveem (Eds.), Oil in the Gulf (pp. 41-62). Aldershot: Ashgate.

Dasgupta, P. S., \& Heal, G. M. (1979). Economic theory and exhaustible resources. Cambridge: Cambridge University Press.

Favennec, J.-P. (2007). Geopolitique de l'energie. Paris: Editions Technip.

Hotelling, H. (1931). The economics of exhaustible resources. Journal of Political Economy, 39(2), 137-175.

IEA. (2015). World energy outlook. Paris: OECD/IEA.

Jacobs, T. J. (2015). Waste heat recovery potential of advanced internal combustion engine technologies. Journal of Energy Resources Technology, 137(4).

Luciani, G. (1990). Allocation vs. production states: A theoretical framework. In G. Luciani (Ed.), The Arab state. London: Routledge.

Mathismoen, O. (2016, April 8). Vil du lese noe ekstremt positivt? Aftenposten. Retrieved from http://mm. aftenposten.no/kloden-var/blog/8419708

Melberg, E. (2016, April 13). Ingen tro på frys. Dagens Næringsliv.

NAS. (2013). Hidden costs of energy: Unpriced consequences of energy production and use. Washington: US National Academy of Science.

Noreng, $\varnothing$. (2004). The predicament of the Gulf rentier state. In D. Heradstveit \& H. Hveem (Eds.), Oil in the Gulf (pp. 9-40). Aldershot: Ashgate.

OICA. (2015). The International Organization of Motor Vehicle Manufacturers. Retrieved from http://www. oica.net

OPEC. (2015). Annual statistical bulletin. Retrieved from http://www.opec.org

OPEC. (2016). Monthly oil market report (April 2016). Retrieved from http://www.opec.org

Painter, D. (2014). Oil and geopolitics: The oil crises of the 1970s and the cold war. Historical Social Research, 39(4), 186-208.

Raval, A., Sheppard, D., \& Hume, N. (2016, April 19). Favoured son emerges as main voice on Saudi energy policy-How the first global oil deal in 15 years came undone after prince intervened. Financial Times.

Sorrell, S. (2007). The rebound effect: An assessment of the evidence for economy-wide energy savings from improved energy efficiency. London: UK Energy Research Centre.

Stevens, P. (2016). International oil companies: The death of the old business model. London: The Royal Institute of International Affairs, Chatham House.

The Economist. (2016a, January 30). Buttonwood. The crazy world of credit. Where negative yields and worries about default coincide. The Economist. Retrieved from http://www.economist.com

The Economist. (2016b, February 6). Oil companies. In the dark ages. Supermajors suffer from self-inflicted wounds as well as falling oil prices. The Economist. Retrieved from http://www.economist.com

Tunsjø, Ø. (2013). Security and profit in China's energy policy. Hedging against risk. New York: Columbia University Press.

World Bank. (2016a). Data collected from the World Bank data base. Retrieved from http://data.world bank.org/indicator/NY.GDP.PETR.RT.ZS

World Bank. (2016b). Data collected from the World Bank data base. Retrieved from http://donnees. banquemondiale.org/indicator/TX.VAL.FUEL.ZS.UN? view=chart

\section{About the Authors}

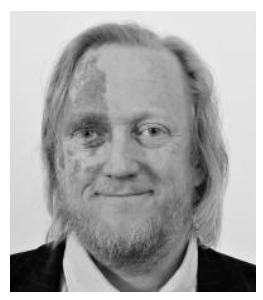

Dag Harald Claes is professor at the Department of Political Science, University of Oslo. He specializes in international energy relations, in particular studies of oil-producer cooperation, the energy relations between Norway and the EU, the role of oil in Middle East conflicts, and Arctic oil and gas. His publications include: The Politics of Oil-Producer Cooperation (Westview Press 2001); Governing the Global Economy-Politics, Institutions and Economic Development (Routledge 2011, edited with Carl Henrik Knutsen). 


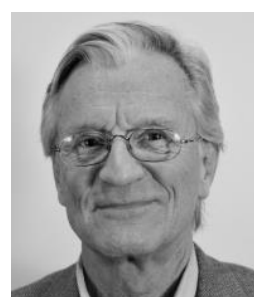

Helge Hveem is professor emeritus at the Department of Political Science, University of Oslo. He has written and taught widely in International Relations with an emphasis in International Political Economy, development studies and the "Third World", knowledge and technology as power sources, and the politics of international investments and the transnational corporations. His publications include The Political Economy of Third World Producer Associations (Universitetsforlaget, 1978); The Global Governance of Knowledge Creation and Diffusion (Routledge, 2011, edited with Lelio lapadre); and Technology, Innovation and Governance (Routledge, 2012, edited with Carl Henrik Knutsen). 